High-Performance Materials and Systems Research Program

\title{
Evaluation of Alkyd Primers
}

Orange S. Marshall, Jr., and Alfred D. Beitelman

November 2000

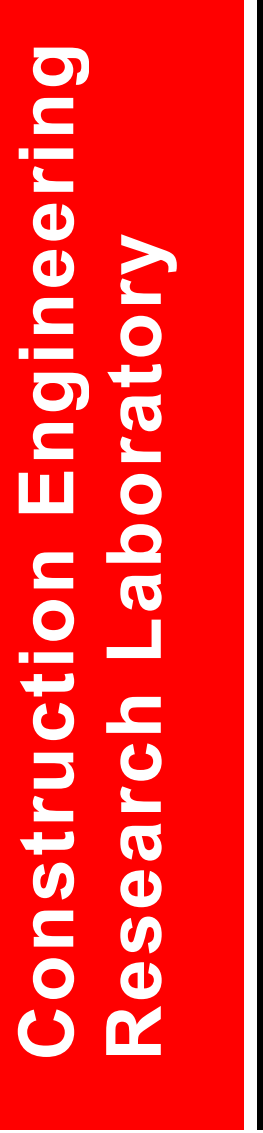

Approved for public release; distribution is unlimited. 
The contents of this report are not to be used for advertising, publication, or promotional purposes. Citation of trade names does not constitute an official endorsement or approval of the use of such commercial products.

The findings of this report are not to be construed as an official Department of the Army position, unless so designated by other authorized documents. 


\section{Evaluation of Alkyd Primers}

by Orange S. Marshall, Jr., and Alfred D. Beitelman

Construction Engineering Research Laboratory

U.S. Army Engineer Research and Development Center

P.O. Box 9005

Champaign, IL 61826-9005

Final report

Approved for public release; distribution is unlimited

Prepared for U.S. Army Corps of Engineers

Washington, DC 20314-1000

Under $\quad$ Work Unit 33109 


\section{Contents}

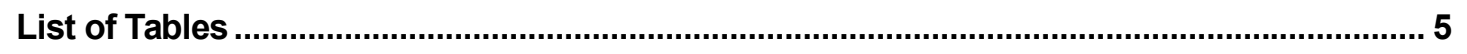

Preface

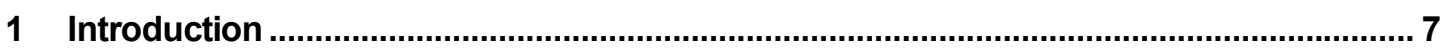

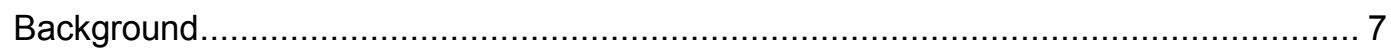

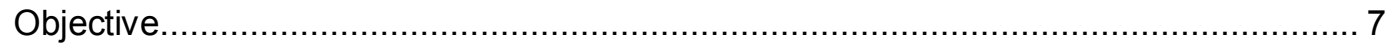

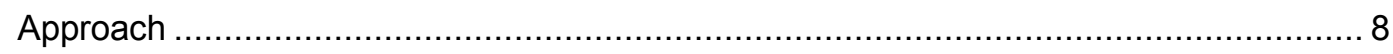

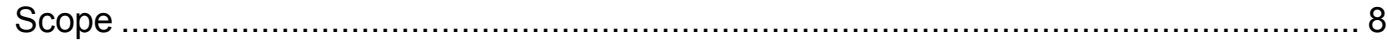

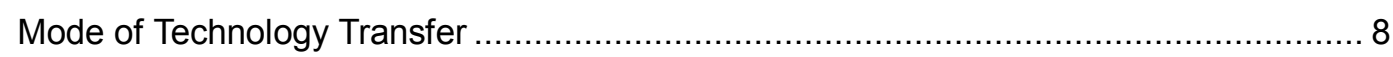

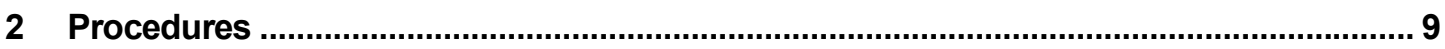

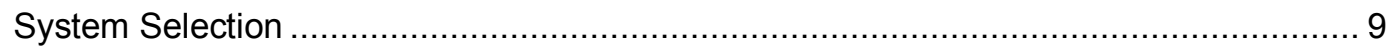

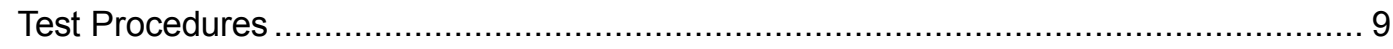

VOC Content

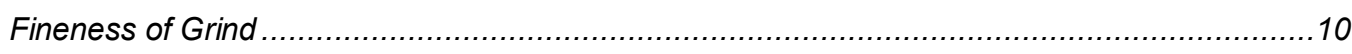

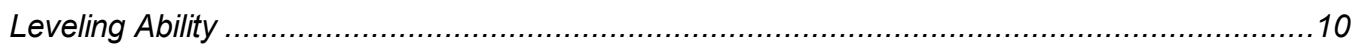

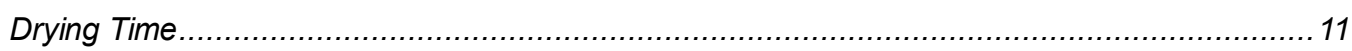

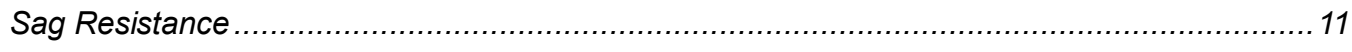

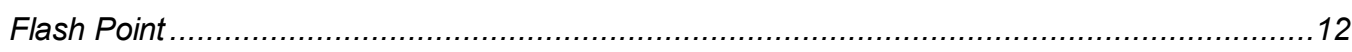

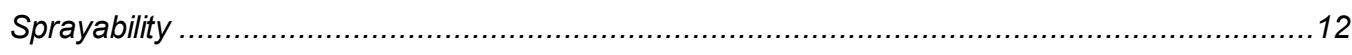

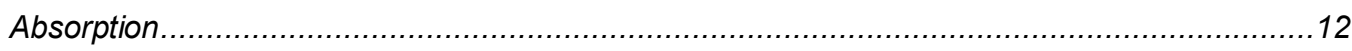

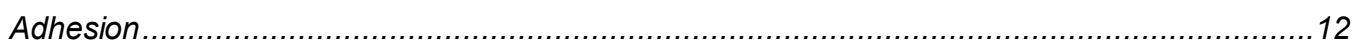

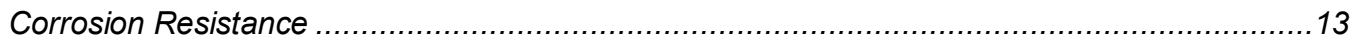

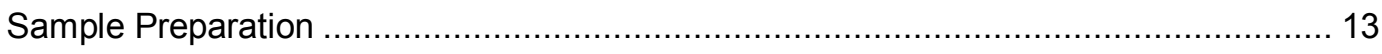

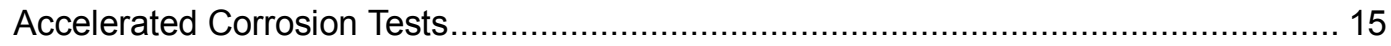

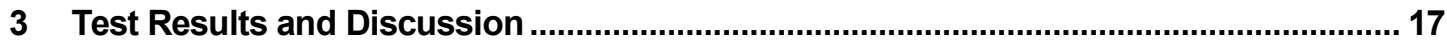

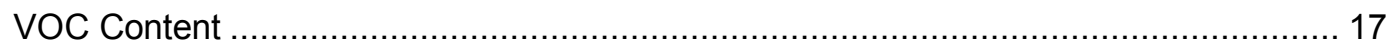

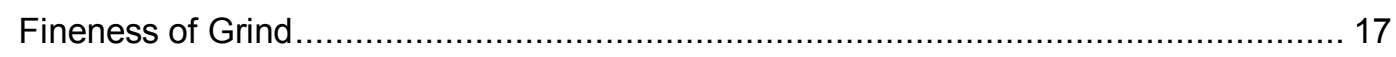

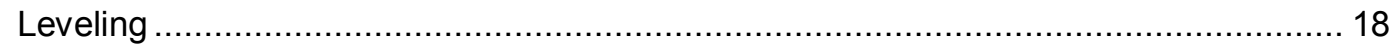

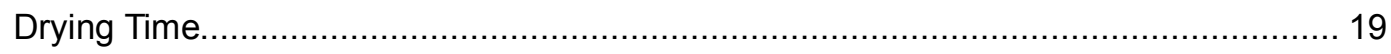

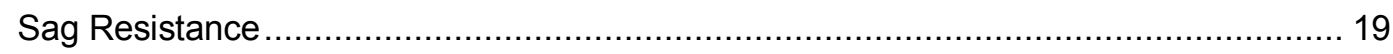

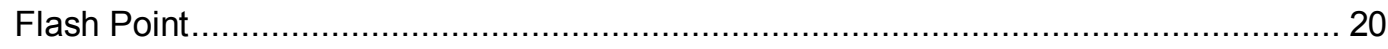

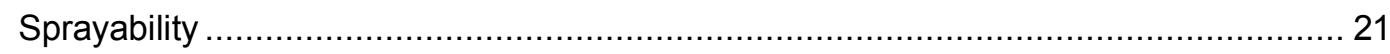




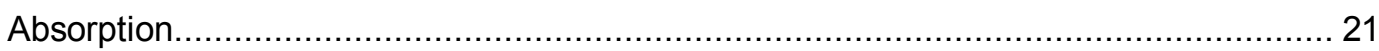

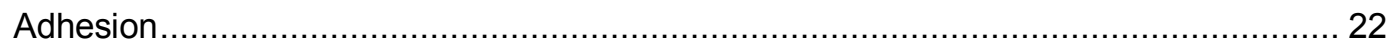

4 Conclusions

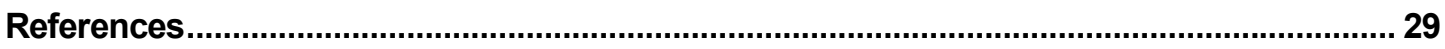

Appendix A: Draft CID for Alkyd Primer (For Application to Dry Steel Surfaces) ............... 31

SF 298 


\section{List of Tables}

\section{Tables}

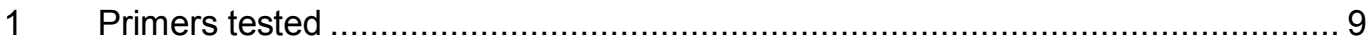

2 Dry film thickness of primer applied to each test panel .................................. 13

3 Dry film thickness of first topcoat applied to each primer ................................ 14

$4 \quad$ Dry film thickness of second topcoat applied to each panel .............................. 14

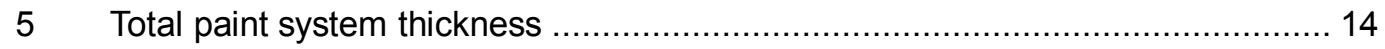

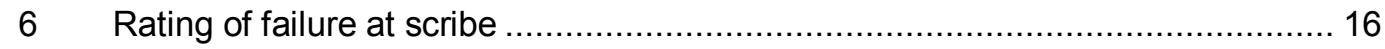

$7 \quad$ VOC content of evaluated alkyd paint primers ............................................... 17

$8 \quad$ Fineness of grind of evaluated alkyd primers............................................... 18

$9 \quad$ Leveling test results of evaluated primers................................................... 18

10 Drying time test results for evaluated primers............................................. 19

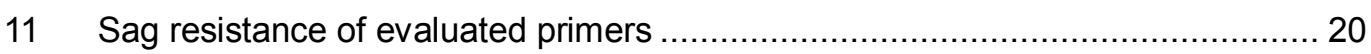

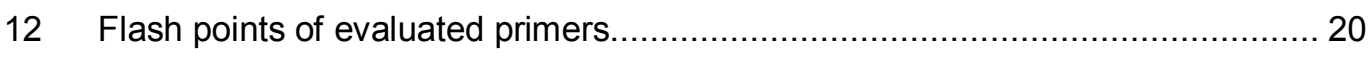

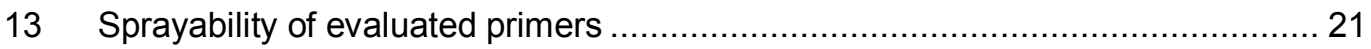

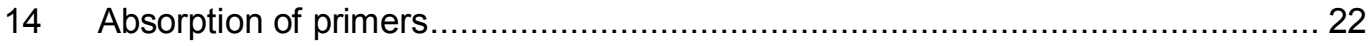

15 Average adhesion test results of evaluated primers with no environmental

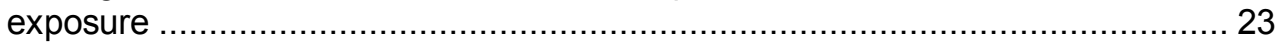

16 Average adhesion test results of evaluated primers following environmental

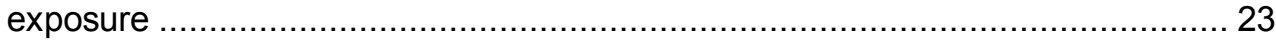

17 Rust test results of evaluated primers ......................................................... 24

18 Blister test results of evaluated primers....................................................... 25

19 Undercutting of rust from scribe test results of evaluated primers ....................... 25

20 Rating of blistering at scribe test results of evaluated primers.......................... 26

21 Composite exposure rating for pre-rusted panels ......................................... 26

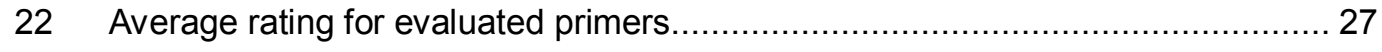

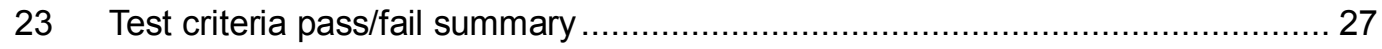




\section{Preface}

The study described in this report was authorized by Headquarters, U.S. Army Corps of Engineers (USACE), as part of the High-Performance Materials and Systems (HPM\&S) Research Program. The work was performed under under Work Unit 33109, "High-Performance Paint Systems, Phase I," for which Mr. Alfred D. Beitelman, U.S. Army Engineer Research and Development Center (ERDC) Construction Engineering Research Laboratory (CERL), was the Principal Investigator.

Dr. Tony C. Liu was the HPM\&S Coordinator at the Directorate of Research and Development; Research Area Manager was Mr. Roy Braden; and Program Monitor was Mr. Andy Wu, HQUSACE. Dr. Mary Ellen Hynes, ERDC Geotechnical and Structures Laboratory (GSL), was the ERDC Lead Technical Director for Infrastructure Engineering and Management. Mr. James E. McDonald, ERDC GSL, was the HPM\&S Program Manager.

The work was performed by the Materials and Structures Branch (CF-M) of the Facilities Division (CF), CERL. The report was prepared by Mr. Orange S. Marshall, Jr., and Mr. Beitelman. Mr. Martin J. Savoie was Chief, CF-M, and Mr. L. Michael Golish was Chief, CF. Dr. Paul Howdyshell was the associated Technical Director. The Acting Director of CERL was Mr. William D. Goran.

At the time of preparation of this report, Dr. James R. Houston was Director of ERDC. COL James S. Weller, EN, was Commander.

\section{DIS C L A IMER}

The contents of this report are not to be used for advertising, publication, or promotional purposes. Citation of trade names does not constitute an official endorsement or approval of the use of such commercial products. All product names and trademarks cited are the property of their respective owners.

The findings of this report are not to be construed as an official Department of the Army position unless so designated by other authorized documents.

DESTROY THIS REPORT WHEN IT IS NO LONGER NEEDED. DO NOT RETURN IT TO THE ORIGINATOR. 


\section{Introduction}

\section{Background}

Alkyd paint systems have been used for decorating and protecting wood and metals worldwide since the ancient Romans discovered that certain seed oils were capable of forming rubbery films when exposed to the air. The term "alkyd" describes a wide range of natural and synthetic oil-based paint systems.

The U.S. Army Corps of Engineers and other Federal agencies use Steel Structures Painting Council (SSPC) Paint Specification No. 25, Red Iron Oxide, Zinc Oxide, Raw Linseed Oil and Alkyd Primer (Without Lead and Chromate Pigments), when specifying a primer for alkyd topcoats. These coating systems are used for interior and exterior applications for steel where it is normally dry.

SSPC-Paint 25 is a formulation-based product and is not readily available in the marketplace. In compliance with Federal policy to use commercial, off-the-shelf (COTS) items wherever possible, it is desirable to have performance-based specifications as opposed either to Federal or military specifications or to formulation-based industry specifications. One method to comply with the Federal policy and still have competitive procurement is to develop Commercial Item Descriptions (CIDs). These government specifications describe COTS products with a specific level of quality. To develop the CID, commercial products must be evaluated to ensure that they are readily available in the open market and can provide a satisfactory level of performance.

\section{Objective}

The objective of this research was to evaluate the performance and potential utility of commercially available alkyd primers in order to develop a CID for them. 


\section{Approach}

Eleven commercially available long oil alkyd primer coatings and an SSPC-Paint 25 control were applied to steel test plates and topcoated with a TT-E-489 gloss enamel topcoat. The test coatings were evaluated using laboratory tests designed to simulate exterior atmospheric weathering of poorly cleaned steel in a marine environment. Test panels were evaluated periodically for degree of rusting, blistering, and rust undercutting.

\section{Scope}

This study was limited to a laboratory evaluation. Laboratory test exposures can be used to measure the relative performance levels of different coatings. However, care should be taken not to extrapolate the results of laboratory experiments to actual field performance. Field tests should be conducted to fully validate the utility of any coating technology. The results contained in this report do not represent an endorsement of specific products or manufacturers.

\section{Mode of Technology Transfer}

It is recommended that the information contained in this report be used as a basis for developing a CID for alkyd primers as replacements for SSPC-Paint 25. 


\section{Procedures}

\section{System Selection}

Manufacturers of alkyd primers within the United States were identified using paint buyers guides from the Journal of Protective Coatings and Linings, Painting and Decorating Contractors of America, and Modern Paint and Coatings. Researchers contacted 14 manufacturers by telephone and requested alkyd primer samples. The manufacturers were told that the primers were to be applied to steel substrates, both cleaned and lightly rusted, and exposed to conditions simulating a severe atmospheric environment. Six manufacturers provided 11 primers for inclusion in the tests. Table 1 lists the primers included.

Table 1. Primers tested.

\begin{tabular}{|l|c|c|}
\hline \multicolumn{1}{|c|}{ Manufacturer } & Color & Primer Nomenclature \\
\hline \multirow{2}{*}{ Sherwin-Williams } & Brown & Kem Kromic Universal \\
\cline { 2 - 3 } & Red & Kem Bond HS \\
\hline \multirow{2}{*}{ Induron Coatings, Inc. } & Red & P10 \\
\cline { 2 - 3 } & Gray & P20 \\
\cline { 2 - 3 } & Tan & P30 \\
\hline \multirow{2}{*}{ Benjamin Moore \& Co. } & Red & M06 \\
\cline { 2 - 3 } & Red & M07 \\
\hline \multirow{2}{*}{ Hempel Coatings (USA), Inc. } & Red & 12180 \\
\cline { 2 - 3 } & Red & 121 US \\
\hline Tnemec Co., Inc. & Red & Series 10 \\
\hline California Products Corp. & Red & Primeline 1705 \\
\hline Indmar & Red & SSPC-Paint 25 \\
\hline
\end{tabular}

\section{Test Procedures}

Each primer in this study was evaluated for the following properties: volatile organic compound (VOC) content, fineness of grind, leveling ability, drying time, sag resistance, flash point, sprayability, and absorption. The primers were also topcoated with two coats of a standard alkyd topcoat and evaluated for intercoat adhesion and system corrosion resistance. Each of the evaluations performed is described in the following paragraphs. 


\section{VOC Content}

The VOC content of coatings is used to estimate the quantity of organic compounds potentially released into the atmosphere during a painting operation. The U.S. Environmental Protection Agency (EPA) and state and local environmental protection agencies have set limits on the amount of organic compounds that a paint system can contain. The Material Safety Data Sheets (MSDSs) and product data sheets for each primer were examined and the VOC content for each primer was determined based on the manufacturer's data.

\section{Fineness of Grind}

In making pigmented products such as paints and primers, the pigment and other fillers are milled into the vehicle. It is necessary to be able to judge the size of these agglomerates and whether they have been sufficiently broken up so as not to interfere with the smoothness of the finished coating film.

To evaluate this characteristic, each primer was evaluated in accordance with American Society for Testing and Materials (ASTM) D 1210, Test Method for Fineness of Dispersion of Pigment-Vehicle Systems by Hegman-Type Gage. The test consisted of spreading the primer by means of a scraper in a calibrated tapered trough. At a point in this trough, particles, agglomerates, or both become visible. A direct reading from a calibrated scale on the test apparatus was made at the point where the particles formed a definite pattern.

\section{Leveling Ability}

The ability of a primer to level once it has been applied is an important aesthetic property, especially for brush-applied coatings. Leveling can affect the hiding and appearance of applied architectural coatings.

The procedure in ASTM D 4062, Test Method for Leveling of Paints by DrawDown Method, was used to evaluate the leveling ability of each primer. The material to be tested was presheared using a high-speed stirrer and applied to a sealed chart by means of a special leveling test blade designed to lay down a film with parallel ridges that simulate brush marks. The chart was allowed to dry in a horizontal position. Leveling of the test primer was then rated by viewing the draw-down under a strong, oblique light source and comparing the contrast of lightness and shadow caused by the paint ridges to that of a series of plastic leveling standards under the same lighting conditions. 


\section{Drying Time}

Knowing drying times for primers is important in planning painting operations. This information is necessary, for example, in determining when top coats may be applied to primers. ASTM D 1640, Standard Test Methods for Drying, Curing or Film Formation of Organic Coatings at Room Temperature, contains a test procedure for determining drying times. The primer for each test was mixed for 2 minutes on a paint shaker, and 1.5 mils (dry film thickness) of primer was spread in a uniform width onto a piece of plate glass using an adjustable doctor blade. The test panel was laid on a table and the primer allowed to dry in a wellventilated laboratory free from drafts and dust in diffused light (not direct sunlight). The temperature of the air within the room was $23^{\circ} \mathrm{C}$.

The set-to-touch and dry-hard times for the films were evaluated according to ASTM D 1640. The Set-to-Touch Time is the lapsed time between film application and when the film is dry enough to lightly touch with the tip of the finger without any of it adhering to the finger. The Dry-Hard Time is the time lapsed when, while holding the glass plate between the thumb and forefinger, after exerting a maximum downward pressure (without twisting) of the thumb on the film, the resulting thumb print can be completely removed by lightly polishing the contacted area with a soft cloth.

\section{Sag Resistance}

The sag resistance of each primer was evaluated according to ASTM D 4400, Test Methods for Sag Resistance of Paints Using a Multinotch Applicator. Evaluation of sag resistance is essential in quality control for both producers and purchasers of coatings. Practical application tests are poor in reproducibility while viscometric methods are time consuming and lack the convincing aspect of actual sagging. This method provides simple and rapid tests, whereby sag resistance is demonstrated by a visible sag pattern and is rated objectively in terms of numerical values that correlate with brushout test observations. Procedure A of ASTM D 4400 was used to evaluate each primer.

After preshearing to duplicate the breakdown in structure that occurs when thixotropic paints are applied by brushout or other practical application methods such as spraying, the primer was applied to a test chart with a multinotch applicator. The chart was immediately hung vertically with the draw-down stripes horizontal, similar to the rungs of a ladder, with the thinnest stripe at the top. After drying in this position, the draw-down was examined and rated for sagging. 


\section{Flash Point}

Flash point is one of the properties used to define the flammability of a liquid and to classify liquids according to their flammability by governmental regulatory agencies. ASTM D 3278, Test Methods for Flash Point of Liquids by Setaflash Closed-Cup Apparatus, was followed in determining the flash point or lowest temperature at which the material flashes for each of the primers evaluated.

\section{Sprayability}

When accelerated corrosion test panels were being prepared, the spraying properties of the primers were evaluated. A DeVilbiss Model MBC spray gun with E tip and needle, \#30 air cap, and an atomization pressure of 55 psi was used to apply the primers to the panels.

\section{Absorption}

The ability of primers to penetrate into poorly cleaned surfaces was evaluated according to Fed-Std-141C, Method 4421, Absorption Test. The test procedure requires filling a paint can lid with the test primer and placing a filter paper onto the surface of the paint. After 3 hours the distance the paint has penetrated the filter paper is measured.

\section{Adhesion}

Adhesion of the primers and two top coats with a standard alkyd paint was evaluated according to ASTM D 3359, Test Methods for Measuring Adhesion by Tape Test, Test Method A. Although test method B is more suitable to laboratory testing, it is not considered suitable for films thicker than 5 mils. The test specimens have more than 5-mil thickness of coating applied to them, so test method A was used. Both clean steel panels and pre-rusted steel panels prepared for accelerated corrosion testing were used. This test is used to assess the adhesion of coating films to metallic substrates and each top coat by applying and removing pressure-sensitive tape over cuts made in the film. An X-cut was made in the film to the substrate; pressure-sensitive tape was applied over the cut and then removed. The adhesion was then assessed qualitatively on a scale of 0 to 5 , with 5 being no removal and 0 being removal from beyond the area of the $\mathrm{X}$ cut. 


\section{Corrosion Resistance}

The corrosion resistance of the primers was evaluated in accordance with ASTM D 5894, Practice for Cyclic Corrosion/UV Exposure of Painted Metal (Alternating Exposures in a Fog / Dry Cabinet and a UV/Condensation Cabinet).

\section{Sample Preparation}

Two sets of A-36 steel Q-panels were prepared. A set of pre-rusted panels was prepared according to SSPC ME-1, Test Panel Preparation Method No. 1, Uncontaminated Rusted Steel. The preparation procedure requires that the steel be abrasive blasted followed by a pre-rusting process. The other set was abrasive blasted to the SSPC SP-10, Near White Metal Blast Cleaning grade, using aluminum oxide grit in a blasting cabinet. Each panel was stamped with an identification number to designate the primer to be applied, the sample number, and if it was pre-rusted.

Each primer being evaluated was spray applied in accordance with manufacturer recommendations and top coated with two coats of TT-E-489 Enamel, Alkyd, Gloss (For Exterior and Interior Surfaces). All paint was spray applied with the equipment previously described. The blast profiles for all panels as measured by replica tape averaged 2 mils. Tables 2 through 5 list dry film thickness and the total paint thickness applied to each test panel. "SB" panels were those with an SSPC SP-10, Near White Metal Blast Cleaning only, and the "R" panels were those that were pre-rusted.

Table 2. Dry film thickness of primer applied to each test panel.

\begin{tabular}{|l|c|c|c|c|c|c|c|c|c|c|}
\hline \multirow{2}{*}{ Primer } & \multicolumn{9}{|c|}{ Primer DFT (mils) } \\
\cline { 2 - 11 }$y$ & SB 1 & SB 2 & SB 3 & SB 4 & R 1 & R 2 & R 3 & R 4 & R 5 \\
\hline Kem Kromic & 4.6 & 3.6 & 3.8 & 3.5 & 4 & 3.5 & 4.8 & 4.6 & 3.8 \\
\hline Kem Bond HS & 3.3 & 3.2 & 3.5 & 3.0 & 2.6 & 2.8 & 3.2 & 3.5 & 2.6 \\
\hline P10 & 4.2 & 3.0 & 3.5 & 3.3 & 4.3 & 4.3 & 4.5 & 4.2 & \\
\hline P20 & 3.5 & 3.2 & 4.2 & 3.8 & 3.5 & 3.3 & 3.5 & 4.2 & \\
\hline P30 & 4.3 & 3.0 & 3.8 & 3.3 & 5.6 & 3.6 & 5.0 & 5.8 & \\
\hline M06 & 4.3 & 3.2 & 3.5 & 3.8 & & 2.3 & 2.8 & 3.0 & 3.2 & \\
\hline M07 & 2.5 & 3.6 & 2.3 & 3.0 & & 2.2 & 1.8 & 2.5 & 2.2 & \\
\hline 12180 & 3.0 & 3.2 & 2.8 & 4.2 & 4.3 & 3.0 & 2.8 & 3.2 & \\
\hline 121 US & 4.3 & 3.2 & 3.5 & 3.3 & & 2.5 & 2.8 & 2.8 & 3.0 & \\
\hline Series 10 & 2.5 & 2.8 & 3.3 & 4.2 & & 3.0 & 2.6 & 3.2 & 3.2 & \\
\hline Primeline 1705 & 2.2 & 3.3 & 3.5 & 4.5 & & 2.5 & 2.5 & 2.8 & 3.3 & \\
\hline SSPC-Paint 25 & 2.1 & 2.1 & 1.8 & 2.3 & & 2.1 & 1.9 & 2.1 & 2.1 & \\
\hline
\end{tabular}


Table 3. Dry film thickness of first topcoat applied to each primer.

\begin{tabular}{|l|c|c|c|c|c|c|c|c|c|c|}
\hline \multirow{2}{*}{ Primer } & \multicolumn{9}{|c|}{$\mathbf{1}^{\text {st }}$ Topcoat DFT (mils) } \\
\cline { 2 - 11 } & SB 1 & SB 2 & SB 3 & SB 4 & R 1 & R 2 & R 3 & R 4 & R 5 \\
\hline Kem Kromic & 1.3 & 1.3 & 1.8 & 1.3 & 2.0 & 1.8 & 1.5 & 1.6 & 1.6 \\
\hline Kem Bond HS & 1.2 & 1.2 & 1.2 & 1.5 & 1.8 & 1.6 & 1.5 & 1.6 & 2.2 \\
\hline P10 & 2.3 & 1.3 & 1.8 & 1.5 & 2.0 & 1.6 & 2.0 & 1.5 & \\
\hline P20 & 2.0 & 1.2 & 1.6 & 1.6 & 2.0 & 1.8 & 2.0 & 2.2 & \\
\hline P30 & 2.0 & 1.5 & 1.6 & 1.5 & 2.0 & 2.0 & 1.8 & 2.2 & \\
\hline M06 & 2.2 & 1.2 & 1.8 & 1.3 & & 1.6 & 1.3 & 1.2 & 1.5 & \\
\hline M07 & 1.6 & 1.0 & 1.5 & 1.5 & & 2.2 & 1.8 & 2.3 & 2.5 & \\
\hline 12180 & 1.3 & 1.3 & 1.3 & 1.6 & & 1.3 & 1.2 & 1.2 & 1.0 & \\
\hline 121 S S & 2.0 & 1.2 & 1.0 & 1.5 & & 1.6 & 1.3 & 1.3 & 1.8 & \\
\hline Series 10 & 1.3 & 1.0 & 1.2 & 1.2 & & 1.3 & 1.3 & 1.3 & 1.6 & \\
\hline Primeline 1705 & 1.6 & 1.3 & 1.3 & 1.3 & & 2.0 & 2.2 & 1.3 & 1.6 & \\
\hline SSPC-Paint 25 & 2.4 & 2.0 & 2.3 & 2.5 & & 3.3 & 2.9 & 2.4 & 2.0 & \\
\hline
\end{tabular}

Table 4. Dry film thickness of second topcoat applied to each panel.

\begin{tabular}{|l|c|c|c|c|c|c|c|c|c|c|}
\hline \multirow{2}{*}{ Primer } & \multicolumn{9}{|c|}{$\mathbf{2}^{\text {nd }}$ Topcoat DFT (mils) } \\
\cline { 2 - 11 } & SB 1 & SB 2 & SB 3 & SB 4 & R 1 & R 2 & R 3 & R 4 & R 5 \\
\hline Kem Kromic & 1.5 & 1.3 & 2.2 & 1.8 & & 1.8 & 1.7 & 1.8 & 2.3 & 2.1 \\
\hline Kem Bond HS & 2.0 & 2.0 & 2.2 & 2.3 & 2.3 & 1.5 & 1.8 & 1.8 & 2.3 \\
\hline P10 & 1.6 & 1.5 & 1.5 & 2.3 & & 1.6 & 1.6 & 1.6 & 1.3 & \\
\hline P20 & 1.8 & 2.2 & 2.3 & 2.2 & 1.6 & 1.6 & 1.8 & 1.8 & \\
\hline P30 & 1.6 & 2.2 & 2.0 & 2.3 & & 1.5 & 1.5 & 1.2 & 1.6 & \\
\hline M06 & 1.5 & 2.3 & 2.2 & 2.2 & & 1.6 & 1.8 & 1.3 & 1.8 & \\
\hline M07 & 1.6 & 2.3 & 2.0 & 2.3 & & 1.6 & 1.8 & 1.6 & 1.8 & \\
\hline 12180 & 1.6 & 2.0 & 1.6 & 1.8 & & 1.6 & 1.8 & 2.0 & 2.3 & \\
\hline $121 U S$ & 1.6 & 2.3 & 2.0 & 2.3 & & 1.6 & 1.5 & 1.6 & 1.6 & \\
\hline Series 10 & 1.6 & 2.2 & 2.0 & 2.5 & & 1.6 & 1.8 & 1.6 & 1.5 & \\
\hline Primeline 1705 & 1.8 & 1.8 & 1.8 & 2.6 & & 1.8 & 1.8 & 1.5 & 2.0 & \\
\hline SSPC-Paint 25 & 3.5 & 3.6 & 3.3 & 3.0 & & 3.1 & 2.9 & 3.5 & 3.6 & \\
\hline
\end{tabular}

Table 5. Total paint system thickness.

\begin{tabular}{|l|c|c|c|c|c|c|c|c|c|c|}
\hline \multirow{2}{*}{ Primer } & \multicolumn{9}{|c|}{ Total System Thickness (mils) } \\
\cline { 2 - 11 } & SB 1 & SB 2 & SB 3 & SB 4 & R 1 & R 2 & R 3 & R 4 & R 5 \\
\hline Kem Kromic & 7.2 & 6.3 & 7.5 & 6.6 & 7.8 & 7.0 & 8.2 & 8.6 & 7.5 \\
\hline Kem Bond HS & 6.5 & 6.3 & 6.5 & 6.8 & 6.8 & 6.0 & 6.5 & 7.0 & 7.2 \\
\hline P10 & 8.2 & 5.8 & 6.8 & 7.2 & & 8.0 & 7.6 & 8.2 & 7.0 & \\
\hline P20 & 7.6 & 6.5 & 8.2 & 7.6 & 7.2 & 6.8 & 7.3 & 8.2 & \\
\hline P30 & 7.6 & 6.6 & 7.5 & 7.6 & 9.2 & 7.1 & 8.0 & 9.6 & \\
\hline M06 & 8.0 & 6.6 & 7.2 & 7.0 & & 5.5 & 6.0 & 5.5 & 6.5 & \\
\hline M07 & 5.8 & 7.0 & 5.8 & 6.8 & & 6.0 & 5.5 & 6.5 & 6.5 & \\
\hline 12180 & 6.0 & 6.6 & 5.8 & 7.6 & & 7.3 & 6.0 & 6.0 & 6.5 & \\
\hline 121 US & 8.0 & 6.6 & 6.5 & 7.2 & & 5.8 & 5.6 & 5.8 & 6.5 & \\
\hline Series 10 & 5.5 & 6.0 & 6.5 & 7.8 & & 6.0 & 5.8 & 6.2 & 6.6 & \\
\hline Primeline 1705 & 5.6 & 6.5 & 6.6 & 8.5 & & 6.3 & 6.5 & 5.5 & 7.0 & \\
\hline SSPC-Paint 25 & 8.0 & 7.7 & 7.4 & 7.8 & & 8.5 & 7.7 & 8.0 & 7.7 & \\
\hline
\end{tabular}




\section{Accelerated Corrosion Tests}

The accelerated corrosion tests consisted of exposing the steel test panels to simulated atmospheric conditions that typically have a deleterious effect on coatings for a period of 24 weeks while periodically evaluating them for development of rusting, blistering, and rust undercutting. The test was conducted in accordance with ASTM D 5894. The procedure requires 1 week in an Atlas ultraviolet/ condensation (UVCON) cabinet operated at 4 hours UV at $60{ }^{\circ} \mathrm{C}$ and 4 hours condensing at $40{ }^{\circ} \mathrm{C}$ using UVA bulbs, followed by 1 week in a Q-Fog Prohesion/ Salt Spray cabinet operated using alternating salt spray $\left(30{ }^{\circ} \mathrm{C}\right.$ using a solution of $4.0 \mathrm{~g} / \mathrm{L}$ of ammonium sulfate and $0.5 \mathrm{~g} / \mathrm{L}$ of sodium chloride for 1 hour) and forced air drying ( 1 hour at $40{ }^{\circ} \mathrm{C}$ ). The test panels were exposed at a 60 -degree angle. A total of 12 cycles were conducted.

Following completion of every two cycles of ASTM D 5894 exposure, the test panels were evaluated for rusting, blistering, and rust undercutting. The exposed surface of each panel was examined for rust development according to ASTM D 610, Test Method for Evaluating Degree of Rusting on Painted Steel Surfaces, and the evaluation results recorded. The panels were then evaluated for blistering according to ASTM D 714, Test Method for Evaluating Degree of Blistering of Paints, and finally for rust undercutting according to ASTM D 1654, Test Method for Evaluation of Painted or Coated Specimens Subjected to Corrosive Environments. The evaluation results for these tests were also recorded.

ASTM D 610 covers the evaluation of the degree of rusting on painted steel surfaces using visual standards. These visual standards were developed in cooperation with the SSPC to further standardize the estimating of the degree of rusting. This test method provides a standardized means for quantifying the amount of rust present. ASTM D 714 uses photographic reference standards to evaluate the degree of blistering that may develop when paint systems are subjected to conditions that will cause blistering. This test method provides a standard procedure of describing the size and density of the blisters so that comparisons of severity can be made. ASTM D 1654 consists of scribing the test panel with a straight line $\mathrm{V}$ cut through the coating to the substrate and then exposing the sample to accelerated and atmospheric exposure tests. Specimens are evaluated by measuring the maximum spread of rust out from the scribe and converting that length to a rating number. Table 6 lists the rating of failure at the scribe. 
Table 6. Rating of failure at scribe.

\begin{tabular}{|c|c|c|}
\hline \multicolumn{2}{|c|}{ Representative Mean Creepage from Scribe* } \\
\hline Millimeters & $\begin{array}{c}\text { Inches } \\
\text { (Approximate) }\end{array}$ & Rating Number \\
\hline 0 & 0 & 10 \\
\hline 0 to 0.5 & 0 to $1 / 64$ & 9 \\
\hline 0.5 to 1.0 & $1 / 64$ to $1 / 32$ & 8 \\
\hline 1.0 to 2.0 & $1 / 32$ to $1 / 16$ & 7 \\
\hline 2.0 to 3.0 & $1 / 16$ to $1 / 8$ & 6 \\
\hline 3.0 to 5.0 & $1 / 8$ to $3 / 16$ & 5 \\
\hline 5.0 to 7.0 & $3 / 16$ to $1 / 4$ & 4 \\
\hline 7.0 to 10.0 & $1 / 4$ to $3 / 8$ & 3 \\
\hline 10.0 to 13.0 & $3 / 8$ to $1 / 2$ & 2 \\
\hline 13.0 to 16.0 & $1 / 2$ to $5 / 8$ & 1 \\
\hline 16.0 or more & $5 / 8$ or more & 0 \\
\hline
\end{tabular}

* From ASTM D 1654 


\section{Test Results and Discussion}

\section{VOC Content}

The 1999 National VOC Rule limits the amount of VOC manufacturers may use in various classes of coatings, including the maximum recommended amount of thinner. That maximum for "industrial maintenance" is $450 \mathrm{~g} / \mathrm{L}$. State and local regulations may further reduce that amount. Table 7 lists the VOC content published by each primer manufacturer for those primers evaluated.

Table 7. VOC content of evaluated alkyd paint primers.

\begin{tabular}{|l|c|c|}
\hline Primer Nomenclature & $\begin{array}{c}\text { Meets } \\
\text { Voc Content } \\
\text { (g/L) }\end{array}$ & $\begin{array}{c}\text { Maximum } \\
\text { Allowable } \\
\text { VOC Level }\end{array}$ \\
\hline Kem Kromic Universal & 415 & Yes \\
\hline Kem Bond HS & 304 & Yes \\
\hline P10 & 403 & Yes \\
\hline P20 & 406 & Yes \\
\hline P30 & 414 & Yes \\
\hline M06 & 453 & Yes \\
\hline M07 & 418 & Yes \\
\hline 12180 & 339 & Yes \\
\hline $121 U S$ & 367 & Yes \\
\hline Series 10 & 383 & Yes \\
\hline Primeline 1705 & 450 & Yes \\
\hline SSPC-Paint 25 & 290 & Yes \\
\hline
\end{tabular}

\section{Fineness of Grind}

The minimum fineness allowable for SSPC-Paint 25 primer is 3.0. Table 8 lists the fineness of grind measured for each primer sample evaluated and rates them according to the criteria for SSPC-Paint 25. All of the primers evaluated meet the SSPC-Paint 25 criteria except the P30 primer. 
Table 8. Fineness of grind of evaluated alkyd primers.

\begin{tabular}{|l|c|c|}
\hline Primer Nomenclature & $\begin{array}{c}\text { Fineness of } \\
\text { Grind }\end{array}$ & $\begin{array}{c}\text { Meets SSPC- } \\
\text { Paint 25 } \\
\text { Criteria }\end{array}$ \\
\hline Kem Kromic Universal & 6.5 & Yes \\
\hline Kem Bond HS & 6.0 & Yes \\
\hline P10 & 3.5 & Yes \\
\hline P20 & 5.5 & Yes \\
\hline P30 & 2.5 & No \\
\hline M06 & 6.0 & Yes \\
\hline M07 & 6.5 & Yes \\
\hline 12180 & 6.0 & Yes \\
\hline 121 S & 6.0 & Yes \\
\hline Series 10 & 6.0 & Yes \\
\hline Primeline 1705 & 3.5 & Yes \\
\hline SSPC-Paint 25 & 6.0 & Yes \\
\hline
\end{tabular}

\section{Leveling}

Leveling is not addressed by the SSPC-Paint 25 specification. It is the opinion of the researcher that a rating of 3 or less will not result in an acceptably smooth surface when brush applied. Table 9 shows the results of the leveling tests performed on each of the evaluated primers. Only 5 out of the 11 primers meet this criterion: Kem Bond HS, P10, M06, M07, and Series 10.

Table 9. Leveling test results of evaluated primers.

\begin{tabular}{|l|c|c|}
\hline \multicolumn{1}{|c|}{ Primer Nomenclature } & Leveling & $\begin{array}{c}\text { Meets } \\
\text { Minimum } \\
\text { Criteria }\end{array}$ \\
\hline Kem Kromic Universal & 2 & No \\
\hline Kem Bond HS & 9 & Yes \\
\hline P10 & 5 & Yes \\
\hline P20 & 2 & No \\
\hline P30 & 2 & No \\
\hline M06 & 7 & Yes \\
\hline M07 & 5 & Yes \\
\hline 12180 & 1 & No \\
\hline 121 S & 2 & No \\
\hline Series 10 & 7 & Yes \\
\hline Primeline 1705 & 0 & No \\
\hline SSPC-Paint 25 & 4 & Yes \\
\hline
\end{tabular}




\section{Drying Time}

The maximum time allowable in SSPC-Paint 25 primers to dry to the set-totouch level is 10 hours. The maximum dry-hard time is 24 hours. Table 10 lists the measured drying times for the primers that were evaluated and the manufacturer's recommended recoat time. All of the primers evaluated met the set-to-touch maximum of 10 hours. Kem Bond HS, P30, and 12180, however, did not meet the dry-hard criterion.

Table 10. Drying time test results for evaluated primers.

\begin{tabular}{|c|c|c|c|c|}
\hline \multirow[b]{2}{*}{ Primer Nomenclature } & \multicolumn{3}{|c|}{ Dry Time (hr) } & \multirow{2}{*}{$\begin{array}{c}\text { Mfr } \\
\text { Recoat } \\
\text { Time } \\
\text { (hr) }\end{array}$} \\
\hline & $\begin{array}{l}\text { Set-To- } \\
\text { Touch }\end{array}$ & Dry-Hard & $\begin{array}{c}\text { Meets SSPC- } \\
\text { Paint } 25 \\
\text { Standard } \\
\end{array}$ & \\
\hline Kem Kromic Universal & 1.5 & 3.5 & Yes & 2.5 \\
\hline Kem Bond HS & 4.0 & 246 & No & 6 \\
\hline P10 & 2 & 16 & Yes & 3 \\
\hline P20 & 2 & 20 & Yes & 3 \\
\hline P30 & 6 & 30 & No & 18 \\
\hline M06 & 6.0 & 22.0 & Yes & 3 \\
\hline M07 & 1.5 & 6.0 & Yes & 1 \\
\hline 12180 & 6.0 & 31 & No & 7 \\
\hline 121US & 1 & 24 & Yes & 8 \\
\hline Series 10 & 3.5 & 6.5 & Yes & 12 \\
\hline Primeline 1705 & 2.0 & 4.0 & Yes & 8.0 \\
\hline SSPC-Paint 25 & 10 & 24 & --- & 24 \\
\hline
\end{tabular}

\section{Sag Resistance}

The minimum sag resistance allowable for SSPC-Paint 25 is 6 mils. If a performance specification is developed for COTS products, however, the sag resistance requirement should equal or exceed the maximum thickness at which the manufacturer recommends the product to be applied. Table 11 shows the sag test results for the evaluated primers. Of the systems evaluated, six met or exceeded the 6 -mil minimum criterion, and all but one met the sag requirement at the manufacturer's maximum recommended thickness. 
Table 11. Sag resistance of evaluated primers.

\begin{tabular}{|l|c|c|c|c|}
\hline Primer Nomenclature & $\begin{array}{c}\text { Manufacturer's } \\
\text { Recommended } \\
\text { WFT }\end{array}$ & $\begin{array}{c}\text { Sag } \\
\text { Resistance }\end{array}$ & $\begin{array}{c}\text { Meets SSPC- } \\
\text { Paint 25 } \\
\text { Criteria }\end{array}$ & $\begin{array}{c}\text { Meets } \\
\text { Manufacturer's } \\
\text { Max. Thickness } \\
\text { Criteria }\end{array}$ \\
\hline Kem Kromic Universal & $6-8$ & 15.6 & Yes & Yes \\
\hline Kem Bond HS & $3-8$ & 5.2 & No & No \\
\hline P10 & $2-4.8$ & 5.6 & No & Yes \\
\hline P20 & $2-4.8$ & 5.8 & No & Yes \\
\hline P30 & $4-7$ & 6.8 & Yes & Yes \\
\hline M06 & 4.8 & 4.8 & No & Yes \\
\hline M07 & 3.8 & 7.8 & Yes & Yes \\
\hline 12180 & 3 & 17.6 & Yes & Yes \\
\hline 121 S & 4 & 5.8 & No & Yes \\
\hline Series 10 & $3.5-6.5$ & 6.0 & Yes & No \\
\hline Primeline 1705 & $3-4$ & 29 & Yes & Yes \\
\hline SSPC-Paint 25 & 3 & 7 & Yes & Yes \\
\hline
\end{tabular}

\section{Flash Point}

The primer flash point specified by SSPC-Paint 25 is $38^{\circ} \mathrm{C}\left(100{ }^{\circ} \mathrm{F}\right)$. The Code of Federal Regulations (29 CFR 1910.106) uses the value of $16.7^{\circ} \mathrm{C}\left(73{ }^{\circ} \mathrm{F}\right)$ as a limit for Class IC Flammable Liquids. Table 12 shows the flash point measured for each of the evaluated primers. If the flash point is too low, the danger of accidental fires increases, especially in confined spaces. For safety purposes, therefore, the flash point should be above the ambient air temperature when used. Of the primers evaluated, only four (Kem Bond HS, M06, 1218O, and Series 10 primers) met or exceeded the minimum temperature criteria.

Table 12. Flash points of evaluated primers.

\begin{tabular}{|l|c|c|c|}
\hline Primer Nomenclature & $\begin{array}{c}\text { Flash Point } \\
\left({ }^{\circ} \mathbf{F}\right)^{\mathbf{1}}\end{array}$ & $\begin{array}{c}\text { Meets SSPC- } \\
\text { Paint } \mathbf{2 5}\end{array}$ & $\begin{array}{c}\text { Meets Class } \\
\text { IC Criteria } \\
\left(\mathbf{7 3}^{\mathbf{}} \mathbf{} \mathbf{F}\right)\end{array}$ \\
\hline Kem Kromic Universal & 80 & No $)$ & Yes \\
\hline Kem Bond HS & 103 & Yes & Yes \\
\hline P10 & 45 & No & No \\
\hline P20 & 45 & No & No \\
\hline P30 & 45 & No & No \\
\hline M06 & 107 & Yes & Yes \\
\hline M07 & 83 & No & Yes \\
\hline 12180 & 100 & Yes & Yes \\
\hline $121 U S$ & 77 & No & Yes \\
\hline Series 10 & 100 & Yes & Yes \\
\hline Primeline 1705 & 80 & No & Yes \\
\hline SSPC-Paint 25 & 105 & Yes & Yes \\
\hline${ }^{1}$ To obtain Celsius (C) temperature readings from Fahrenheit (F) readings, \\
use the following formula: C $=(5 / 9)($ F-32).
\end{tabular}




\section{Sprayability}

Fed-Std-141C, Method 4331.1, Paint, Varnish, Lacquer and Related Materials: Methods of Inspection, Sampling, and Testing, requires that the primer spray satisfactorily in all respects, and shall show no running, sagging, or fogging. The dried film shall not show dusting, floating, mottling, bubbling, wrinkling, streaking, pinholes, cratering, orange peel, blushing, blooming, or silking. Table 13 rates each of the evaluated primers according to these criteria. Primeline 1705, the only one to fail the criteria, failed due to its viscosity. The primer in the can approaches the consistency of a paste. To be used either by brushing or by spraying, the maximum recommended amount of solvent recommended by the manufacturer must be used. Additionally, the primer is so thick that it is difficult to mix in the solvent.

Table 13. Sprayability of evaluated primers.

\begin{tabular}{|l|c|}
\hline Primer Nomenclature & $\begin{array}{c}\text { Meets Federal } \\
\text { Standards } \\
\text { Criteria }\end{array}$ \\
\hline Kem Kromic Universal & Yes \\
\hline Kem Bond HS & Yes \\
\hline P10 & Yes \\
\hline P20 & Yes \\
\hline P30 & Yes \\
\hline M06 & Yes \\
\hline M07 & Yes \\
\hline 12180 & Yes \\
\hline $121 U S$ & Yes \\
\hline Series 10 & Yes \\
\hline Primeline 1705 & No \\
\hline SSPC-Paint 25 & Yes \\
\hline
\end{tabular}

\section{Absorption}

Absorption is not a test requirement of SSPC-Paint 25; however, it is a requirement that the paint be formulated with a high percentage of raw linseed oil. The formulation requirement assures that the paint will have the ability to penetrate into crevices and poorly cleaned surfaces. Fed-Std-141C, Method 4421, Absorption Test, places a value on the amount of penetration. Observation of the filter papers at the end of the test noted that the M06 and Primeline 1705 did not reveal any penetration of the paper. Primers P20 and M07 only partially penetrated the paper. Most products penetrated the paper to the extent that a uniform color was visible. Primer 121US was glossy over the 
entire wetted area but did not penetrate beyond the ring of the lid. Table 14 lists the absorption of the primers evaluated. Of all the commercial primers tested, only the Hempel 12180 produced any measurable test result, which was far short of the result for the SSPC-Paint 25 control. It is unknown if the level of penetration noted with SSPC-Paint 25 is actually necessary to adequately penetrate into rust scale, crevices of lap joints, and under rivets; however, it is assumed that some measurable level of penetration is necessary.

Table 14. Absorption of primers.

\begin{tabular}{|l|c|}
\hline Primer Nomenclature & $\begin{array}{c}\text { Absorption } \\
\text { (mm) }\end{array}$ \\
\hline Kem Kromic Universal & 0 \\
\hline Kem Bond HS & 0 \\
\hline P10 & 0 \\
\hline P20 & $0^{\text {b }}$ \\
\hline P30 & 0 \\
\hline M06 & $0^{\mathrm{a}}$ \\
\hline M07 & $0^{\mathrm{b}}$ \\
\hline 12180 & 1.2 \\
\hline 121 S & 0 \\
\hline Series 10 & 0 \\
\hline Primeline1705 & $0^{\mathrm{a}}$ \\
\hline SSPC-Paint 25 (Standard) & 9 \\
\hline
\end{tabular}

(a) Paint did not penetrate the thickness of the paper

(b) Paint only partially penetrated the thickness of the paper

\section{Adhesion}

SSPC-Paint 25 does not address adhesion. Other specifications (e.g., TT-P-664D) state that the panel cannot show any removal of the primer by the adhesive tape beyond 1/16 inch (3A) on either side of the score line. Table 15 shows the average of three adhesion tests followed by the rating range. Table 16 shows the same information following 12 cycles of environmental exposure.

Prior to exposure, all of the primers met the minimum criteria for adhesion to the substrate. All except Kem Bond HS also showed adequate adhesion between the primer and the topcoat. After undergoing 12 cycles of accelerated corrosion testing, four primers (Kem Bond HS, M06, 12180, and Series 10) still exhibited the minimum degree of adhesion. 
Table 15. Average adhesion test results of evaluated primers with no environmental exposure.

\begin{tabular}{|l|c|c|c|c|c|}
\hline \multirow{2}{*}{ Primer Nomenclature } & \multicolumn{2}{|c|}{ SP-10 Panels } & \multicolumn{2}{c|}{ Pre-Rusted Panels } & \multirow{2}{*}{ Meets Criteria } \\
\cline { 2 - 5 } & Substrate & Primer & Substrate & Primer & Yes \\
\hline Kem Kromic Universal & 5.0 & 4.0 & 5.0 & 4.0 & Yes \\
\hline Kem Bond HS & 5.0 & 1.0 & 5.0 & 3.7 & Yes \\
\hline P10 & 5.0 & 5.0 & 3.7 & 4.0 & Yes \\
\hline P20 & 5.0 & 4.3 & 4.7 & 4.7 & Yes \\
\hline P30 & 5.0 & 5.0 & 5.0 & 4.7 & Yes \\
\hline M06 & 5.0 & 5.0 & 5.0 & 5.0 & Yes \\
\hline 12180 & 5.0 & 5.0 & 5.0 & 3.7 & Yes \\
\hline $121 U S$ & 5.0 & 5.0 & 5.0 & 4.7 & Yes \\
\hline Series 10 & 5.0 & 3.7 & 5.0 & 5.0 & Yes \\
\hline Primeline 1705 & 5.0 & 5.0 & 5.0 & 5.0 & Yes \\
\hline SSPC-Paint 25 & 5.0 & 4.3 & 5.0 & 3.7 & Yes \\
\hline
\end{tabular}

Table 16. Average adhesion test results of evaluated primers following environmental exposure.

\begin{tabular}{|l|c|c|c|c|c|}
\hline \multirow{2}{*}{ Primer Nomenclature } & \multicolumn{3}{|c|}{ Average Adhesion Rating } & \multirow{2}{*}{} \\
\cline { 2 - 5 } & \multicolumn{2}{|c|}{ SP-10 Panels } & \multicolumn{2}{c|}{ Pre-Rusted Panels } & \multirow{2}{*}{ Meets Criteria } \\
\cline { 2 - 6 } & Substrate & Primer & Substrate & Primer & No \\
\hline Kem Kromic Universal & 5.0 & 1.3 & 1.3 & N/A & \multirow{2}{*}{ Yes } \\
\hline Kem Bond HS & 4.7 & 4.0 & 3.7 & 2.7 & No \\
\hline P10 & 1.3 & N/A & 4.7 & 1.7 & No \\
\hline P20 & 1.7 & N/A & 1.3 & N/A & No \\
\hline P30 & 1.0 & N/A & 1.7 & N/A & Yes \\
\hline M06 & 4.7 & 2.0 & 4.7 & 2.3 & No \\
\hline M07 & 2.0 & N/A & 5.0 & 2.7 & Yes \\
\hline 12180 & 4.7 & 3.0 & 5.0 & 2.0 & No \\
\hline $121 U S$ & 2.3 & N/A & 1.7 & 1.3 & Yes \\
\hline Series 10 & 5.0 & 2.0 & 5.0 & 1.3 & No \\
\hline Primeline 1705 & 2.3 & N/A & 1.7 & N/A & Yes \\
\hline SSPC-Paint 25 & 5.0 & 3.6 & 5.0 & 3.6 & \\
\hline
\end{tabular}

It is the researcher's opinion that based on other criteria (e.g., TT-P-664D), the test specimens should show no more than a trace of rusting (No. 9, ASTM D 610) and no more than a few No. 8 (ASTM D 714) blisters, none larger than $1 \mathrm{~mm}$ in diameter. Table 17 shows test results following 12 cycles of environmental exposure, and Table 18 lists the blister test results. Rust and blister undercutting along the scribe should not extend beyond a 6 rating (ASTM D 1654), and blisters forming along the scribe should be no larger than $2 \mathrm{~mm}$ (ASTM D 714 Size No. 4) in diameter. Table 19 shows the average undercutting for the three panels tested for each configuration, and Table 20 lists the average blister undercutting and size for the panels along the scribe. 
All systems meet the minimum rust standard. Only two systems, M07 and 121US, showed no rusting in the environmentally exposed area. None of the primers exhibited problems with blistering. After 4,032 hours of exposure, 12180 and Series 10 primers were beginning to show some initiation of blistering, but were within the minimum criteria range. Only 12180 failed the rust undercutting criterion in both SP-10 and pre-rusted panels. Kem Bond HS, M07, and 121US did not meet the rust undercutting criterion for the pre-rusted panels, while P30 did meet this criterion for the pre-rusted panels but failed for the SP-10 panels. All other panels met the criterion for both types of panels. This result indicates that Kem Kromic Universal, P10, P20, M07, Series 10, and Primeline 1705 were able to absorb into the rust on the panel surfaces better than the other primers.

After 4,032 hours of accelerated corrosion exposure, all of the panels exhibited some blistering along the edge of the scribe. Some were extensive with large blisters while others were not as bad. Panels with Primeline 1705 were the only ones to meet the minimum criteria for both SP-10 prepared panels and prerusted panels. The series 10 primer met the minimum criteria on the pre-rusted panels, and P10 and P20 did for the SP-10 panels.

Table 17. Rust test results of evaluated primers.

\begin{tabular}{|l|c|c|c|}
\hline \multirow{2}{*}{ Primer Nomenclature } & \multicolumn{2}{|c|}{ Average Rating } & \multirow{2}{*}{$\begin{array}{c}\text { Meets } \\
\text { Rusting } \\
\text { Criteria }\end{array}$} \\
\cline { 2 - 3 } & $\begin{array}{c}\text { SP-10 Blasted } \\
\text { Panels }\end{array}$ & $\begin{array}{c}\text { Pre-Rusted } \\
\text { Panels }\end{array}$ & Yes \\
\hline Kem Kromic Universal & 9 & 9 & Yes \\
\hline Kem Bond HS & 9 & 9 & Yes \\
\hline P10 & 9 & 9 & Yes \\
\hline P20 & 9 & 9 & Yes \\
\hline P30 & 9 & 9 & Yes \\
\hline M06 & 9 & 9 & Yes \\
\hline M07 & 10 & 10 & Yes \\
\hline 12180 & 9 & 9 & Yes \\
\hline 121 S & 10 & 10 & Yes \\
\hline Series 10 & 9 & 9 & Yes \\
\hline Primeline 1705 & 9 & 9 & Yes \\
\hline SSPC-Paint 25 (Standard) & 10 & 9 & \\
\hline
\end{tabular}


Table 18. Blister test results of evaluated primers.

\begin{tabular}{|l|c|c|c|}
\hline Primer Nomenclature & $\begin{array}{c}\text { Blister Rating } \\
\text { for SP-10 } \\
\text { Blasted } \\
\text { Panels }\end{array}$ & $\begin{array}{c}\text { Blister Rating } \\
\text { for } \\
\text { Pre-Rusted } \\
\text { Panels }\end{array}$ & $\begin{array}{c}\text { Meets } \\
\text { Blister } \\
\text { Criteria }\end{array}$ \\
\hline Kem Kromic Universal & 10 & 10 & Yes \\
\hline Kem Bond HS & 10 & 10 & Yes \\
\hline P10 & 10 & 10 & Yes \\
\hline P20 & 10 & 10 & Yes \\
\hline P30 & 10 & 10 & Yes \\
\hline M06 & 10 & 10 & Yes \\
\hline M07 & 10 & 10 & Yes \\
\hline 12180 & $9 \mathrm{~F}$ Localized & $8 \mathrm{~F} \mathrm{Localized}$ & Yes \\
\hline $121 U S$ & 10 & 10 & Yes \\
\hline Series 10 & $9 \mathrm{~F}$ & $8 \mathrm{~F}$ & Yes \\
\hline Primeline 1705 & 10 & 10 & Yes \\
\hline SSPC-Paint 25 (Standard) & 10 & 10 & Yes \\
\hline
\end{tabular}

Table 19. Undercutting of rust from scribe test results of evaluated primers.

\begin{tabular}{|c|c|c|c|}
\hline \multirow[b]{2}{*}{ Primer Nomenclature } & \multicolumn{2}{|c|}{$\begin{array}{c}\text { Average Rust Undercutting } \\
\text { Rating }\end{array}$} & \multirow[b]{2}{*}{$\begin{array}{c}\text { Meets Minimum } \\
\text { Criteria }\end{array}$} \\
\hline & $\begin{array}{c}\text { SP-10 Blasted } \\
\text { Panels }\end{array}$ & $\begin{array}{l}\text { Pre-Rusted } \\
\text { Panels }\end{array}$ & \\
\hline Kem Kromic Universal & 7.3 & 6.7 & Yes \\
\hline Kem Bond HS & 7.7 & 5.3 & SP-10 Blast Only \\
\hline $\mathrm{P} 10$ & 6.0 & 6.3 & Yes \\
\hline P20 & 6.7 & 6.0 & Yes \\
\hline P30 & 5.0 & 6.3 & Pre-Rusted Only \\
\hline M06 & 6.0 & 5.0 & SP-10 Blast Only \\
\hline M07 & 6.7 & 6.0 & Yes \\
\hline 12180 & 4.7 & 5.0 & No \\
\hline 121US & 7.0 & 5.0 & SP-10 Blast Only \\
\hline Series 10 & 6.0 & 7.0 & Yes \\
\hline Primeline 1705 & 6.3 & 6.7 & Yes \\
\hline SSPC-Paint 25 (Standard) & 8.8 & 6.7 & Yes \\
\hline
\end{tabular}


Table 20. Rating of blistering at scribe test results of evaluated primers.

\begin{tabular}{|l|c|c|c|c|c|}
\hline \multirow{2}{*}{$\begin{array}{l}\text { Primer } \\
\text { Nomenclature }\end{array}$} & $\begin{array}{c}\text { SSPC 10 Blasted Panels } \\
\text { Average } \\
\text { Under- } \\
\text { cutting }\end{array}$ & $\begin{array}{c}\text { Maximum } \\
\text { Blister Size }\end{array}$ & $\begin{array}{c}\text { Pre-Rusted Panels } \\
\text { Average } \\
\text { Undercutting }\end{array}$ & $\begin{array}{c}\text { Maximum } \\
\text { Blister Size }\end{array}$ & $\begin{array}{c}\text { Meets } \\
\text { Minimum } \\
\text { Criteria }\end{array}$ \\
\hline Kem Kromic Universal & 5.3 & 6 & 5.3 & 6 & Yes \\
\hline Kem Bond HS & 5.0 & 6 & 5.0 & 6 & Yes \\
\hline P10 & 6.3 & 6 & 4.7 & 5 & Yes \\
\hline P20 & 6.3 & 6 & 5.3 & 6 & Yes \\
\hline P30 & 4.0 & 5 & 3.7 & 5 & Yes \\
\hline M06 & 4.3 & 5 & 4.0 & 5 & Yes \\
\hline M07 & 5.3 & 5 & 5.0 & 6 & Yes \\
\hline 12180 & 4.3 & 4 & 4.0 & 4 & Yes \\
\hline $121 U S$ & 3.7 & 5 & 3.0 & 6 & Yes \\
\hline Series 10 & 4.7 & 6 & 6.3 & 6 & Yes \\
\hline Primeline 1705 & 6.7 & 6 & 6.3 & 6 & Yes \\
\hline SSPC-Paint 25 (Standard) & 7.2 & 6 & 6.0 & 4 & Yes \\
\hline
\end{tabular}

CID A-A-3132 requires that pre-rusted panels be exposed to the cyclic exposure test for a total of 4,032 hours. At the end of the exposure, the panel values for the rusting on the panels, rust undercutting at the scribe, and blister rating at the scribe are combined for a single composite rating (Table 21).

According to the requirements of this specification, all but four of the primers meet the composite requirement, but only one meets the requirements for undercutting at the scribe, and it does not meet the blistering requirement. SSPC-Paint 25 also falls short of meeting the undercutting requirement but is among the higher performing primers. The test procedure appears to be valid for the products, but the requirement must be lowered to 6 . Table 22 shows the average rating for the primers evaluated.

Table 21. Composite exposure rating for pre-rusted panels.

\begin{tabular}{|l|c|}
\hline Test & $\begin{array}{c}\text { A-A-3132 } \\
\text { Minimum } \\
\text { Value }\end{array}$ \\
\hline General rusting on panels (Rating) & 10 \\
\hline Blister rating at scribe at 4032 hours (Average) & 8 \\
\hline Rust undercutting at scribe (Average of 6, Rating) & 7 \\
\hline Composite of averages (Rust + Blister + Undercut) & 25 \\
\hline
\end{tabular}


Table 22. Average rating for evaluated primers.

\begin{tabular}{|l|c|c|c|c|}
\hline \multirow{2}{*}{ Primer Nomenclature } & \multicolumn{4}{|c|}{$\begin{array}{c}\text { Average Rating for } \\
\text { Pre-Rusted Panels }\end{array}$} \\
\cline { 2 - 5 } & Blister & Rust & Scribe & Avg \\
\hline Kem Kromic Universal & 10 & 9 & $\mathbf{6 . 7}$ & 25.7 \\
\hline Kem Bond HS & 10 & 9 & $\mathbf{5 . 3}$ & $\mathbf{2 3 . 3}$ \\
\hline P20 & 10 & 9 & $\mathbf{6 . 0}$ & 25 \\
\hline P30 & 10 & 9 & $\mathbf{6 . 3}$ & 25.3 \\
\hline M06 & 10 & 9 & $\mathbf{5 . 0}$ & $\mathbf{2 4}$ \\
\hline M07 & 10 & 10 & $\mathbf{6 . 0}$ & 26 \\
\hline 12180 & $\mathbf{8}$ & 9 & $\mathbf{5 . 0}$ & $\mathbf{2 2}$ \\
\hline 121 US & 10 & 10 & $\mathbf{5 . 0}$ & 25 \\
\hline Series 10 & $\mathbf{8 ~ F}$ & 9 & 7.0 & 24 \\
\hline Primeline 1705 & 10 & 9 & $\mathbf{6 . 7}$ & 25.7 \\
\hline SSPC-Paint 25 (Standard) & 10 & 9 & $\mathbf{6 . 7}$ & 25.7 \\
\hline
\end{tabular}

Table 23 summarizes all of the evaluations performed, ranked (left to right) from the best performing primer to the least. Designations in the table indicate test results equal to or better than the results for SSPC-Paint 25 and proposed as requirements in a draft CID. None of the primers evaluated completely met all of the test criteria.

Table 23. Test criteria pass/fail summary.

\begin{tabular}{|c|c|c|c|c|c|c|c|c|c|c|c|c|}
\hline Test & \begin{tabular}{|c|} 
SSPC- \\
Paint \\
25 \\
\end{tabular} & M07 & M06 & \begin{tabular}{|c|} 
Kem \\
Kromic \\
Univ. \\
\end{tabular} & $\begin{array}{c}\text { Series } \\
10\end{array}$ & $\begin{array}{c}\text { Kem } \\
\text { Bond } \\
\text { HS }\end{array}$ & P10 & $\mathbf{P 2 0}$ & \begin{tabular}{|c} 
Prime- \\
line \\
1705 \\
\end{tabular} & 121US & 12180 & P30 \\
\hline VOC (450 Max) & $\mathrm{Y}$ & $\mathrm{Y}$ & $\mathrm{Y}$ & $\mathrm{Y}$ & $\mathrm{Y}$ & $\mathrm{Y}$ & $\mathrm{Y}$ & $\mathrm{Y}$ & $\mathrm{Y}$ & $\mathrm{Y}$ & $\mathrm{Y}$ & $\mathrm{Y}$ \\
\hline Grind & $\mathrm{Y}$ & $\mathrm{Y}$ & $\mathrm{Y}$ & $\mathrm{Y}$ & $\mathrm{Y}$ & $\mathrm{Y}$ & $\mathrm{Y}$ & $\mathrm{Y}$ & $\mathrm{Y}$ & $\mathrm{Y}$ & $\mathrm{Y}$ & \\
\hline Leveling & $Y$ & $\mathrm{Y}$ & $Y$ & & $Y$ & $\mathrm{Y}$ & $\mathrm{Y}$ & & & & & \\
\hline Drying time & $Y$ & $Y$ & $Y$ & $Y$ & $Y$ & & $Y$ & $Y$ & $Y$ & $Y$ & & \\
\hline $\begin{array}{l}\text { Sag (Mfg. Max. } \\
\text { Thickness) }\end{array}$ & $\mathrm{Y}$ & $\mathrm{Y}$ & $\mathrm{Y}$ & $\mathrm{Y}$ & & $\mathrm{Y}$ & $\mathrm{Y}$ & $\mathrm{Y}$ & $\mathrm{Y}$ & $\mathrm{Y}$ & $\mathrm{Y}$ & $\mathrm{Y}$ \\
\hline Flash $\left(100^{\circ} \mathrm{F}\right)$ & $\mathrm{Y}$ & & $Y$ & & $\mathrm{Y}$ & $Y$ & & & & & $Y$ & \\
\hline Sprayability & $Y$ & $Y$ & $Y$ & $Y$ & $Y$ & $Y$ & $Y$ & $Y$ & & $Y$ & $Y$ & $\mathrm{Y}$ \\
\hline Absorption & $Y$ & & & & & & & & & & $Y$ & \\
\hline $\begin{array}{l}\text { Adhesion } \\
\text { (Pre-Exposure) }\end{array}$ & $\mathrm{Y}$ & $\mathrm{Y}$ & $\mathrm{Y}$ & $\mathrm{Y}$ & $\mathrm{Y}$ & $\mathrm{Y}$ & $\mathrm{Y}$ & $\mathrm{Y}$ & $\mathrm{Y}$ & $\mathrm{Y}$ & $\mathrm{Y}$ & $\mathrm{Y}$ \\
\hline $\begin{array}{l}\text { Adhesion } \\
\text { (Post-Exposure) }\end{array}$ & $\mathrm{Y}$ & & $\mathrm{Y}$ & & $\mathrm{Y}$ & $\mathrm{Y}$ & & & & & $\mathrm{Y}$ & \\
\hline Blisters (Scribe) & $\mathrm{Y}$ & $\mathrm{Y}$ & $\mathrm{Y}$ & $\mathrm{Y}$ & $\mathrm{Y}$ & $\mathrm{Y}$ & $\mathrm{Y}$ & $\mathrm{Y}$ & $\mathrm{Y}$ & $\mathrm{Y}$ & $\mathrm{Y}$ & $\mathrm{Y}$ \\
\hline Rust & $\mathrm{Y}$ & $\mathrm{Y}$ & $\mathrm{Y}$ & $\mathrm{Y}$ & $\mathrm{Y}$ & $\mathrm{Y}$ & $\mathrm{Y}$ & $\mathrm{Y}$ & $\mathrm{Y}$ & $\mathrm{Y}$ & $\mathrm{Y}$ & $\mathrm{Y}$ \\
\hline Blisters (Panel) & $\mathrm{Y}$ & $\mathrm{Y}$ & $\mathrm{Y}$ & $\mathrm{Y}$ & & $\mathrm{Y}$ & $\mathrm{Y}$ & $\mathrm{Y}$ & $\mathrm{Y}$ & $\mathrm{Y}$ & & $\mathrm{Y}$ \\
\hline $\begin{array}{l}\text { Rust Undercutting } \\
\text { (Scribe) }\end{array}$ & $Y$ & $\mathrm{Y}$ & & $\mathrm{Y}$ & $Y$ & & $\mathrm{Y}$ & $\mathrm{Y}$ & $\mathrm{Y}$ & & & $\mathrm{Y}$ \\
\hline $\begin{array}{l}\text { Composite } \\
\text { (Blister, rust, } \\
\text { scribe) }\end{array}$ & $\mathrm{Y}$ & $\mathrm{Y}$ & & $\mathrm{Y}$ & & & & $\mathrm{Y}$ & $\mathrm{Y}$ & $\mathrm{Y}$ & & $\mathrm{Y}$ \\
\hline
\end{tabular}




\section{Conclusions}

Eleven long alkyd primers were evaluated. None of the primers evaluated completely met all of the test criteria. A CID has been drafted (Appendix A) that would be met by paints meeting the requirements of SSPC-Paint 25; however, with no commercial items meeting all requirements, its use cannot be recommended. 


\section{References}

ASTM D 610, Test Method for Evaluating Degree of Rusting on Painted Steel Surfaces (American Society for Testing and Materials [ASTM], Philadelphia, PA, 1989).

ASTM D 714, Test Method for Evaluating Degree of Blistering of Paints (ASTM 1994).

ASTM D 1210, Test Method for Fineness of Dispersion of Pigment-Vehicle Systems by Hegman-Type Gage (ASTM 1988).

ASTM D 1640, Standard Test Methods for Drying, Curing or Film Formation of Organic Coatings at Room Temperature (ASTM 1995 [reapproved 1999]).

ASTM D 1650, Test Methods for Sampling and Testing Shellac Varnish (ASTM 1991).

ASTM D 1654, Test Method for Evaluation of Painted or Coated Specimens Subjected to Corrosive Environments (ASTM 1992).

ASTM D 3278, Test Methods for Flash Point of Liquids by Setaflash Closed-Cup Apparatus (ASTM 1989).

ASTM D 3359, Method A, Test Methods for Measuring Adhesion by Tape Test (ASTM 1993).

ASTM D 4062, Test Method for Leveling of Paints by Draw-Down Method (ASTM 1993).

ASTM D 4400, Test Methods for Sag Resistance of Paints Using a Multinotch Applicator (ASTM 1993).

ASTM D 5894, Practice for Cyclic Corrosion/UV Exposure of Painted Metal (Alternating Exposures in a Fog/Dry Cabinet and a UV/Condensation Cabinet) (ASTM 1996).

ASTM G 53, Practice for Operating Light- and Water-Exposure Apparatus (Fluorescent UV-

Condensation Type) for Exposure of Nonmetallic Materials (ASTM 1996).

Federal Specification TT-P-664D, Primer Coating, Alkyd, Corrosion-Inhibiting, Lead and Chromate Free, VOC-Compliant, General Services Administration, Auburn, WA, 1992.

Fed-Std-141C, Method 4331.1, Paint, Varnish, Lacquer and Related Materials: Methods of Inspection, Sampling, and Testing, Headquarters, Department of the Army (HQDA), January 1986 with changes March 1992 and December 1993. 
Fed-Std-141C, Method 4421, Absorption Test, HQDA, January 1986 with changes March 1992 and December 1993.

Journal of Protective Coatings and Linings, Technology Publishing Co., Pittsburgh, PA.

Modern Paint and Coatings, Cygnus Publishing Inc., Melville, NY.

SSPC ME-1, Test Panel Preparation Method No. 1, Uncontaminated Rusted Steel (Steel Structures Painting Council [SSPC], Pittsburgh, PA, 1999).

SSPC SP-2, Hand Tool Cleaning (SSPC 1980).

SSPC SP-10, Near White Metal Blast Cleaning (SSPC 1980). 


\section{Appendix A: Draft CID for Alkyd Primer (For Application to Dry Steel Surfaces)}


NOTE: This draft was prepared by DOD-CE and has not been approved and is subject to modification. DO NOT USE FOR ACQUISITION.*

[METRIC]

A-A-XXX

(DATE)

\section{COMMERCIAL ITEM DESCRIPTION}

\section{ALKYD PRIMER (FOR APPLICATION TO DRY STEEL SURFACES)}

The General Services Administration has authorized the use of this commercial item description by all federal agencies.

1. SCOPE. This commercial item description covers a liquid primer for application to abrasive-blasted steel surfaces and power tool-cleaned steel surfaces. The primer is designed for long-term corrosion protection of the steel for both interior and exterior non-immersion exposures.

2. SALIENT CHARACTERISTICS. The primer shall meet the following test requirements:

Table 1. Properties.

\begin{tabular}{|c|c|c|c|}
\hline \multirow[b]{2}{*}{ Characteristics } & \multicolumn{2}{|c|}{ Measurements } & \multirow{2}{*}{$\begin{array}{l}\text { ASTM or FTMS } \\
141 \text { Test Method } \\
\end{array}$} \\
\hline & Min. & Max. & \\
\hline VOC Content (g/L) & - & 450 & D 3960 \\
\hline Fineness of Grind (Hegman Units) & 3 & - & D 1210 \\
\hline Leveling & 4 & - & D 4062 \\
\hline \multicolumn{4}{|l|}{ Drying Time: } \\
\hline Tack Free (hr) & - & 10 & D 1640 \\
\hline Dry Hard (hr) & - & 24 & D 1640 \\
\hline Sag Resistance (mils) & 6 & - & D 4400 \\
\hline
\end{tabular}

* Beneficial comments, recommendations, additions, deletions, clarifications, etc., and any other data that may improve this document should be sent to: General Services Administration, GSA Center (9FTE-10), Auburn, Washington 98001. 


\begin{tabular}{|l|c|c|c|}
\hline \multirow{2}{*}{ Characteristics } & \multicolumn{2}{|c|}{ Measurements } & \multirow{2}{*}{$\begin{array}{c}\text { ASTM or FTMS } \\
\text { 141 Test Method }\end{array}$} \\
\cline { 2 - 4 } & Min. & Max. & D 3278 \\
\hline Flash Point $\left({ }^{\circ} \mathrm{F}\right)$ & 100 & - & Method 4421 \\
\hline Absorption (mm) & 5 & & D 3359 \\
\hline Adhesion & 3 & - & D 610 \\
\hline Accelerated Corrosion: & 10 & - & D 714 \\
$\quad$ Rust & 8 & - & D 1654 \\
$\quad \begin{array}{l}\text { Blisters (4032 hour avg) } \\
\quad \text { Undercutting at scribe (avg) }\end{array}$ & 6 & - & \\
\hline $\begin{array}{l}\text { Sum of blister rating, rust undercutting average } \\
\text { rating, and degree of rusting. }\end{array}$ & 25 & & \\
\hline 1 FTMS - Federal Test Method Standard. & & & \\
\hline
\end{tabular}

2.1 Accelerated Corrosion Test Panel Preparation: Paint for testing shall be applied to steel test panels prepared according to SSPC-ME-1. Manufacturer's published guidance on mixing, thinning, induction time, and recoat time shall be followed. Application shall be evaluated as required below.

2.2 Evaluation of Application: The spray application shall result in a coating of uniform thickness. Pinholes and holidays shall be minimal and shall not extend to the substrate. The dried film shall not show dusting, floating, mottling, bubbling, wrinkling, streaking, cratering, orange peel, blushing, blooming, or silking.

2.3 Evaluation of Performance: After the 28-day immersion, all panels shall be removed and evaluated for evidence of poor performance. The coating shall have a blister rating of 10 when tested according to ASTM D 714. The coating shall have a rust rating of 10 when evaluated according to ASTM D 610. The evaluation shall exclude rust associated with edges and the score on each panel. The coating shall have an adhesion rating of 4 or greater when evaluated according to ASTM D 3359, Method A. The coating shall be probed with a sharp knife along the score. Evidence of decreased adhesion to the substrate or poor intercoat adhesion extending farther than $2 \mathrm{~mm}$ from the scribe shall be considered failure of the coating.

\section{QUALITY ASSURANCE PROVISIONS.}

3.1 Manufacturer Certification. The manufacturer shall certify and maintain substantiating evidence that the product offered meets the salient characteristics of this Commercial Item Description, and that the product conforms to the producer's own specifications, standards, and quality assurance practices. The government reserves the right to require proof of such conformance prior to first 
delivery and thereafter as may be otherwise provided for under the provisions of the contract.

3.2 Market Acceptability. The following market acceptability criteria are necessary to document the quality of the product to be provided under this CID.

3.2.1 The company producing the item must have been producing a product meeting the requirements of this CID for at least 2 years.

3.2.2 The company must have sold 500 gallons meeting this CID in the commercial marketplace over the past 2 years.

4. NOTES.

\section{SOURCE OF DOCUMENTS.}

5.1 The Steel Structures Painting Council (SSPC) specifications for surface preparation are available from SSPC, 4516 Henry St., Pittsburgh, PA 152133728.

5.2 ASTM Standards are available from the American Society for Testing and Materials, 1916 Race Street, Philadelphia, PA 19103.

MILITARY INTERESTS:

Preparing Activity: GSA-FSS 


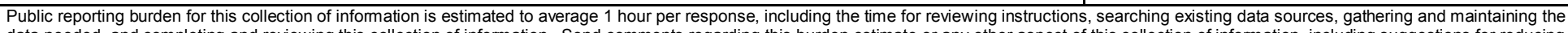

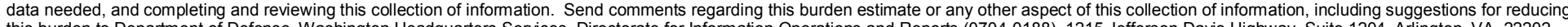

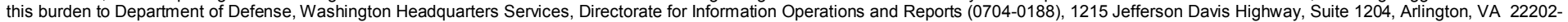

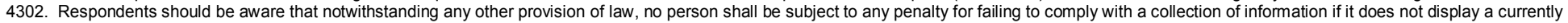
valid OMB control number. PLEASE DO NOT RETURN YOUR FORM TO THE ABOVE ADDRESS.

\begin{tabular}{|l|l|l} 
1. REPORT DATE (DD-MM-YYYY) & 2. REPORT TYPE & 3. DATES COVERED (FrOm - To)
\end{tabular}

Final report

\section{TITLE AND SUBTITLE}

Evaluation of Alkyd Primers

5a. CONTRACT NUMBER

Orange S. Marshall, Jr., and Alfred D. Beitelman

5b. GRANT NUMBER

5c. PROGRAM ELEMENT NUMBER

5d. PROJECT NUMBER

5e. TASK NUMBER

5f. WORK UNIT NUMBER

HPMS WU 33109

\section{PERFORMING ORGANIZATION NAME(S) AND ADDRESS(ES)}

U.S. Army Engineer Research and Development Center

8. PERFORMING ORGANIZATION REPORT NUMBER

Construction Engineering Research Laboratory

ERDC/CERL TR-00-44

P.O. Box 9005

Champaign, IL 61826-9005

\section{SPONSORING / MONITORING AGENCY NAME(S) AND ADDRESS(ES)}

10. SPONSOR/MONITOR'S ACRONYM(S)

U.S. Army Corps of Engineers

Washington, DC 20314-1000

11. SPONSOR/MONITOR'S REPORT

NUMBER(S)

\section{DISTRIBUTION / AVAILABILITY STATEMENT}

Approved for public release; distribution is unlimited.

\section{SUPPLEMENTARY NOTES}

\section{ABSTRACT}

The objective of the research described in this report was to evaluate the performance and potential utility of commercially available alkyd primers in order to develop a Commercial Item Description (CID) for them.

Alkyd paint systems include a wide range of natural and synthetic oil-based paint systems that have been used worldwide since ancient times to decorate and protect wood and metals. The U.S. Army Corps of Engineers and other Federal agencies use Steel Structures Painting Council (SSPC) Paint Specification No. 25, "Red Iron Oxide, Zinc Oxide, Raw Linseed Oil and Alkyd Primer (Without Lead and Chromate Pigments)," when specifying a primer for alkyd topcoats. These coating systems are used for interior and exterior applications for steel where it is normally dry.

SSPC-Paint 25 is a formulation-based product and is not readily available in the marketplace. In compliance with Federal policy to use commercial, off-the-shelf (COTS) items wherever possible, it is desirable to have performance-based specifications as opposed either to Federal or military specifications or to formulation-based industry specifications. One method to comply with the Federal policy and still have competitive procurement is to develop Commercial Item Descriptions, which are government specifications that describe COTS

(Continued)

\begin{tabular}{|c|c|c|c|c|c|}
\hline $\begin{array}{l}\text { 15. SUBJECT TERN } \\
\text { Alkyd paint } \\
\text { Alkyd primer }\end{array}$ & & $\begin{array}{l}\text { Coatings } \\
\text { Commercial iten }\end{array}$ & escrintion & & inted steel \\
\hline 16. SECURITY CLA & IFICATION OF: & & 17. LIMITATION & 18. NUMBER & 19a. NAME OF RESPONSIBLE \\
\hline $\begin{array}{l}\text { a. REPORT } \\
\text { UNCLASSIFIED }\end{array}$ & b. ABSTRACT & $\begin{array}{l}\text { c. THIS PAGE } \\
\text { UNCLASSIFIED }\end{array}$ & & 36 & $\begin{array}{l}\text { 19b. TELEPHONE NUMBER (include area } \\
\text { code) }\end{array}$ \\
\hline
\end{tabular}


14. ABStract. (Concluded)

products with a specific level of quality. To develop a CID, commercial products must be evaluated to ensure that they are readily available in the open market and can provide a satisfactory level of performance.

Eleven commercially available long oil alkyd primer coatings and an SSPC-Paint 25 control were applied to steel test plates and topcoated with a TT-E-489 gloss enamel topcoat. The test coatings were evaluated using laboratory tests designed to simulate exterior atmospheric weathering of poorly cleaned steel in a marine environment. Test panels were evaluated periodically for degree of rusting, blistering, and rust undercutting.

None of the primers evaluated completely met all of the test criteria. The draft CID presented as Appendix A would be met by paints fulfilling the requirements of SSPC-Paint 25 . However, with no commercial items meeting all requirements, use of the draft CID cannot be recommended.

It should be noted that this study was limited to a laboratory evaluation. Care should be taken not to extrapolate the results of laboratory experiments to actual field performance. Field tests should be conducted to fully validate the utility of any coating technology. The results contained in this report do not represent an endorsement of specific products or manufacturers. 